\title{
PENGARUH PENGGUNAAN METODE DRILL PADA MATERI KALOR TERHADAP HASIL BELAJAR FISIKA SISWA
}

\author{
Durrul Jauhariyah $^{1}$, Dardiri ${ }^{2}$ \\ ${ }^{1}$ MAN 1 Bandar Lampung, Jl. Letkol Endro Suratmin, Harapan Jaya, Sukarame, Bandar Lampung. 35131 \\ ${ }^{2}$ Alumni $S_{2}$ Universitas Sebelas Maret Surakarta \\ e-mail: 1durrul_jauhariyah@yahoo.co.id, ${ }^{2}$ masdardiri@gmail.com
}

Diterima: 15 Februari 2017. Disetujui: 10 April 2017. Dipublikasikan: 28 April 2017

\begin{abstract}
Abstrak: Penelitian ini bertujuan untuk mengetahui: (1) perbedaan hasil belajar kognitif siswa yang diajar menggunakan metode drill dengan siswa yang menggunakan metode ceramah; (2) pengaruh penggunaan metode drill terhadap hasil belajar kognitif siswa kelas X MAN 1 Bandar Lampung. Jenis penelitian ini adalah kuasi eksperimen dengan pretest posttest control group design. Populasi pada penelitian ini seluruh siswa kelas X MAN 1 Bandar Lampung. Pengambilan sampel dilakukan dengan teknik cluster random sampling, sehingga terpilih kelas X.MIA 4 sebagai kelas eksperimen dan kelas X.MIA 1 sebagai kelas kontrol. Instrumen yang digunakan adalah soal pre-test dan soal post-test. Teknik analisa data menggunakan uji-t dan regresi. Hasil penelitian menunjukkan bahwa: (1) terdapat perbedaan hasil belajar kognitif siswa yang diajar menggunakan metode drill dengan siswa yang menggunakan metode ceramah yang ditunjukkan oleh nilai signifikansi pada uji t sebesar 0,033 ; (2) terdapat pengaruh penggunaan metode drill terhadap hasil belajar kognitif siswa kelas X MAN 1 Bandar Lampung yang ditunjukkan oleh koefisien regresi positif sebesar 0,758 .
\end{abstract}

Kata kunci: metode drill, hasil belajar, kuasi eksperimen.

\section{THE EFFECT OF DRILL METHOD ON HEAT MATERIAL TOWARD STUDENTS' PHYSICS LEARNING OUTCOMES}

\begin{abstract}
The purpose of this research was (1) the difference of the students' cognitive study results that used drill method and lecture method; (2) the effect of using drill methods concerning the study result of learning in class X MAN 1 Bandar Lampung. This was quasi-experiment research with Pretest-Posttest Control Group Design. The population was all of X grade students of MAN 1 Bandar Lampung. Taking samples in this research was done by a cluster random sampling technique, so X MIA 4 was chosen as the experimental class and XMIA 1 was chosen as the controlling class. The Instrument used in this research consist of pretest and posttest question. Then, the technique of analyzing data used T-test and regression. The results of this research show that (1) there was a difference of the student' cognitive study results that used drill and lecture method with significance of t-test 0,033; (2) there was an effect of using drill method concerning about the students' cognitive study result with coefficient of regression 0,758.
\end{abstract}

๑) 2017 Pendidikan Fisika FTK UIN Raden Intan Lampung

Keywords: drill methods, learning outcomes, quasi-experiment.

\section{PENDAHULUAN}

Prinsip-prinsip kegiatan pembelajaran yang ditekankan oleh Pemerintah melalui Peraturan Menteri Pendidikan dan Kebudayaan Nomor 81A Tahun 2013 adalah kegiatan belajar harus berpusat pada siswa, bermuatan nilai, etika, penalaran, estetika, dan kinestetika. Selain itu, pembelajaran harus dapat membangun kreativitas siswa, memunculkan pengalaman belajar yang bervariasi dengan berbagai strategi, media dan metode pembelajaran yang bermakna, kontekstual, efektif, dan efisien serta menciptakan suasana belajar yang menantang dan menyenangkan.

Untuk menciptakan proses pengalaman belajar didalam kelas maka setiap proses yang dilakukan harus terpusat pada siswa dan bukan terpusat pada guru (teacher 
centered). Hal tersebut sesuai dengan pendapat Ausubel, "belajar merupakan proses dalam menentukan cara agar pengetahuan yang dimiliki dapat diciptakan secara terstruktur dalam dirinya sendiri" (Dahar, 1989). Model pembelajaran yang perlu dihasilkan adalah model yang menumbuhkan semangat dalam menggali ilmu pengetahuan (Joice \& Weil: 1996), tidak hanya terbatas pada jumlah pengetahuan, sikap ataupun keterampilan semata, tetapi hal yang lebih utama adalah bagaimana ketiga aspek tersebut didapatkan siswa melalu kegiatan belajar (Zamroni, 2000).

Masalah yang sering muncul pada sistem pendidikan yaitu masih belum optimalnya kegiatan dalam proses pembelajaran (Sanjaya, 2008). Dalam proses pembelajaran di bangku sekolah, siswa hanya menjalankan rutinitas biasa tanpa diajak dalam kegiatan untuk meningkatkan kemampuan analisisnya. Padahal kegiatan pembelajaran harus dirancang sedemikian rupa agar dapat memberikan ruang kepada siswa dalam menemukan pengalaman belajar secara mandiri yang menyeluruh baik sesama siswa sebagai rekan belajar, maupun dengan guru sebagai fasilitator atau dengan lingkungan sehingga tercapainya kompetensi dasar. Tetapi kenyataanya di sekolah masih menerapkan metode pembelajaran klasikal, sehingga berpengaruh pada hasil yang kurang maksimal.

Pembelajaran klasikal yang diterapkan pada mayoritas lembaga pendidikan masih didominasi dengan ceramah guru tanpa melihat kegiatan belajar siswa. Pembelajaran ini lebih dominan hanya transfer dari guru ke siswa saja atau dilakukan satu arah (teacher centered), menyebabkan pembelajaran terkesan hanya mentransfer pengetahuan dari guru ke siswa saja. Padahal pembelajaran fisika dengan guru sebagai aktor utama pembelajaran sehingga mengesampingkan peran siswa dapat menghambat siswa dalam penguasaan konsep, sikap, dan praktek siswa. Akibatnya hasil akhir dari proses belajar tersebut sangat rendah sehingga berpengaruh pada prestasi belajar siswa.

Hal itu dikuatkan dengan hasil observasi pada kegiatan pembelajaran yang berlangsung di kelas X Madrasah Aliyah Negeri 1 Bandar Lampung yang menunjukkan pemahaman terhadap materi masih rendah. Rendahnya pemahaman materi dapat diperjelas dengan hasil analisis terhadap nilai akhir yang diperoleh siswa lebih khusus pada materi Kalor. Berdasarkan analisis hasil belajar menunjukkan $67 \%$ siswa belum memenuhi Ketuntasan Kompetensi Minimal (KKM) sebesar 76. Hanya 33\% siswa yang telah mencapai KKM pelajaran fisika yang ditetapkan MAN 1 Bandar Lampung. Oleh karena itu, peran dari pendidik sangat dibutuhkan untuk mengatasi permasalahan tersebut.

Guru menjadi faktor penentu tingkat keberhasilan dalam pembelajaran di kelas. Dalam meningkatkan hasil belajar siswa guru harus mampu merubah metode agar kegiatan di kelas menjadi lebih aktif dengan siswa sebagai aktor utama pembelajaran. Alternatif metode yang dapat digunakan adalah latihan berulang atau drill. Melalui metode drill, menjadikan proses belajar siswa lebih bervariasi tidak hanya fokus pada buku atau guru saja melainkan penemuan masalah untuk dicari jawabannya dengan berbagai cara. Setiap proses belajar memiliki titik acuan masing-masing pada kemampuan siswa yang selalu berubah melalui proses read, write, and rewrite (Winkel, 2009).

Metode drill menekankan pada proses latihan yang dilakukan secara berulangulang sehingga kemampuan akhir yang dimiliki siswa akan lebih tinggi dari materi yang sedang ia pelajari. Hal itu ditegaskan oleh Hamalik (2008) yang menjelaskan bahwa drill atau juga sering disebut repetitive drill method adalah 
usaha untuk menekankan pada keterampilan-keterampilan otomatis yang telah diperoleh. Oleh sebab itu, peran dari metode pengajaran ini adalah sebagai suatu usaha untuk membuat kegiatan belajar lebih kondusif dengan menekankan interaksi antar siswa, guru, dan lingkungan sekitar. Dengan metode ini diharapkan muncul keterampilan dasar siswa sehingga membentuk karakter sebagai manusia sosial, yang dapat bergaul dengan sesama dan dapat menyesuaikan dalam situasi sosial yang berbeda-beda saat dia telah selesai dari bangku sekolah.

Beberapa penelitian terdahulu yang membahas metode drill yaitu penelitian oleh Pera Purwati (2010) yang menunjukkan bahwa saat kegiatan belajar menggunakan metode drill ternyata mampu meningkatkan motivasi dan minat belajar siswa. Penelitiaan ini menunjukkan bahwa aktivitas belajar yang lebih aktif mempengaruhi semangat belajar siswa, tetapi dalam penelitian ini belum dicantukmkan pengaruh terhadap prestasi belajar siswa. Kemudian, penelitian oleh Susilowati (2013). Hasil penelitian menunjukkan prestasi siswa XI SMA Negeri Kebakramat semakin meningkat saat kegiatan pembelajaran yang dilakukan oleh guru menggunakan pertanyaan yang bersifat berulang. Tetapi sampel dalam penelitian ini hanya menggunakan satu kelas dengan membandingkan nilai akhir dan awal, sedangkan penelitian yang dilakukan peneliti menggunakan dua kelas untuk dibandingkan kondisi awal dan akhir. Penelitian tentang penggunaan metode drill dalam kegiatan belajar khususnya mata pelajaran fisika juga merupakan hal baru jika dikaitkan dengan prestasi akhir yang diperoleh siswa.

Berdasarkan penjelasan di atas, hasil belajar tidak hanya melibatkan siswa saja tetapi juga perlu kesiapan metode yang digunakan. Untuk itu, dilakukan penelitian tentang pengaruh penggunaan metode drill terhadap hasil belajar fisika siswa kelas X MAN 1 Bandar Lampung. Tujuan penelitian ini adalah untuk mengetahui: (1) perbedaan hasil belajar kognitif siswa yang diajar menggunakan metode drill dengan yang menggunakan metode ceramah; (2) pengaruh penggunaan metode drill terhadap hasil belajar siswa kelas X MAN 1 Bandar Lampung.

\section{LANDASAN TEORI \\ 1. Metode Drill}

Metode drill adalah metode belajar dengan menekankan pada aspek psikomotorik siswa yang dilakukan berulang-ulang dalam mempelajari suatu pengetahuan atau materi (Sriyono: 1992). Pada dasarnya metode drill menekankan kegiatan belajar di kelas dengan objek utama adalah siswa melaksanakan latihan yang bersifat berulang-ulang untuk melatih kemampuan siswa menjadi lebih baik.

Langkah-langkah yang harus dilakukan oleh guru dalam menerapkan metode drill yaitu:

1. Menyiapkan daftar pertanyaan yang dilengkapi dengan jawaban.

2. Mengajukan pertanyaan kepada siswa.

3. Mendengarkan jawaban baik melalui lisan atau memeriksa jawaban tertulis dari siswa.

4. Mengajukan pertanyaan kembali kepada siswa dengan pertanyaan yang sudah diberikan.

Sedangkan tahapan penerapan metode dril yang harus siswa lakukan adalah:

1. Mendengarkan dengan seksama pertanyaan yang diajukan oleh guru.

2. Menjawab pertanyaan baik melalui lisan atau dengan tulisan.

3. Mengulang jawaban sesuai permintaan dari guru.

4. Memperhatikan pertanyaan yang diajukan oleh guru selanjutnya. 
Kelebihan penerapan metode drill dalam pembelajaran menurut Sriyono (1992) yaitu:

1. Materi yang diberikan lebih runtut, langkah demi langkah dan tidak loncat-loncat agar lebih bermakna dalam hati sanubari setiap siswa.

2. Adanya pengawasan,bimbingan dan koreksi dari guru mebuat siswa langsung faham terkait kesalahan yang ia lakukan. Dengan demikian waktu yang digunakan akan lebih efektif.

3. Pengetahuan dan keterampilan yang telah diasah bangku kelas dapat digunakan dalam kehidupannya kelak baik dalam lingkup sosial masyarakat maupun keperluan pada dunia kerja.

Adapun kekurangan dalam menggunakan metode drill yaitu:

1. Menciptakan individu yang statis, sulit berubah.

2. Menciptakan proses penyesuaian diri yang bersifat mekanis di lingkungan sekitarnya.

3. Memunculkan kebiasaan menghafal pada siswa.

4. Kegiatan latihan berulang akan memunculkan perasaan tidak suka dari siswa

5. Proses belajar denga latihan disertai bimbingan guru yang intensif memunculkan rasa bosan pada siswa.

Menurut Roestiyah (2008) beberapa hal yang harus dilakukan guru setiap menerapakan metode drill yaitu menggunakan latihan hanya saat pelajaran dilakukan secara otomatis, guru sebaiknya menggunakan materi sebagai bahan latihan dengan arti yang luas, mengutamakan ketepatan dan memperhitungkan waktu latihan.

Sedangkan Hamalik (2008) menyebutkan beberapa faktor agar metode drill mampu berjalan efektif, yaitu: lingkungan belajar, latihan harus fungsional dan dilaksanakan secara sistematis serta tepat waktu.

\section{Hasil Belajar Siswa}

Hasil belajar siswa adalah kemampuan-kemampuan yang diperoleh siswa setelah melakukan kegiatan/proses dalam pembelajaran. Klasifikasi hasil belajar dari Bloom dibagi dalam tiga ranah yaitu ranah kognitif, ranah afektif, dan ranah psikomotorik (Arikunto, 2010).

Ranah kognitif menggambarkan perilaku yang berhubungan dengan aspek intelektual, seperti kemampuan berpikir, pengetahuan, dan pengertian terhadap suatu hal yang meliputi mengetahui, pemahaman, mengaplikasi, menganalisis, seintesis, dan evaluasi (Wilson: 2006).

Ranah afektif terkait dengan sikap. Ada lima kategori dalam ranah afektif diantaranya menerima, berpartisipasi, dan menilai serta penentuan pendapat, organisasi, dan berkaitan dengan cara hidup.

Ranah psikomotorik terkait skill atau keterampilan. Ranah psikomotorik mendeskripsikan perilaku dari sisi gerakan terbimbing, persepsi, kesiapan, gerakan sederhana, gerakan sulit, penyesuaian gerakan, dan kreativitas.

\section{METODE PENELITIAN}

Penelitian ini termasuk penelitian kuasi eksperimen (quasi experimental research) dengan mempertimbangkan bahwa penelitian ini berusaha untuk mengetahui pengaruh antara satu variabel dengan variabel lainnya dengan mengambil dua kelas sebagai sampel. Penelitian dilaksanakan di MAN 1 Bandar Lampung yang beralamat di Jl. Letnan Kolonel $\mathrm{H}$. Endro Suratmin, Kelurahan Harapan Jaya, Kecamatan Sukarame, Bandar Lampung, Provinsi Lampung pada semester genap tahun ajaran 2015/2016 yaitu pada bulan Februari sampai Maret tahun 2016. Penelitian ini terdiri dimulai dengan observasi awal untuk mengetahui keadaan 
siswa dan pembelajaran sampai pelaksanaan penelitian.

Rancangan eksperimen pada penelitian ini adalah rancangan eksperimen Matching Pretest-Posttest Group Design. Menurut Sukmadinata (2011), secara skematis desain tersebut digambarkan pada tabel 1:

Tabel 1 Gambaran Desain Penelitian

\begin{tabular}{clll}
\hline Kelompok & Pretest & Perlakuan & Posttest \\
\hline X.MIA $_{4}$ & $0_{1}$ & $\mathrm{X}_{1}$ & $0_{2}$ \\
X.MIA $_{1}$ & $0_{3}$ & $\mathrm{X}_{2}$ & $0_{4}$ \\
\hline
\end{tabular}

Keterangan:

$0_{1}$ : Pretest kelas eksperimen

$\mathrm{O}_{2}:$ Posttest kelas eksperimen

$\mathrm{O}_{3}$ : Pretest kelas kontrol

$0_{4}$ : Posttest kelas kontrol

$\mathrm{X}_{1}$ : Kelas dengan metode drill

$\mathrm{X}_{2}$ : Kelas dengan metode ceramah.

Populasi dalam penelitian ini merupakan siswa kelas X semester genap MAN 1 Bandar Lampung tahun ajaran 2015/2016, yang terdiri dari 4 kelas. Dengan teknik pengambilan sampel cluster random sampling (acak sederhana) didapat kelas $\mathrm{X} \quad \mathrm{MIA}_{4}$ menggunakan metode drill dan kelas $\mathrm{X} \mathrm{MIA}_{1}$, menggunakan metode ceramah.

Variabel bebas dalam penelitian ini yaitu metode drill dan metode ceramah. Variabel terikat yang ditentukan adalah hasil belajar fisika siswa.

Data yang dihasilkan dalam penelitian berupa kemampuan kognitif dalam bentuk hasil tes. Hasil belajar siswa diambil dalam bentuk penilaian pengetahuan melalui hasil tes tertulis yang diambil pretest dan post-test berjumlah lima soal uraian.

Instrumen pelaksanaan pembelajaran dalam penelitian ini berupa silabus dan RPP. Instrumen pengambilan data menggunakan tes. Tes digunakan untuk mengukur hasil belajar fisika siswa pada aspek kognitif.
Teknik analisa data dimulai dengan uji normalitas dilanjutkan dengan uji homogenitas dari data yang telah diperoleh, kemudian dilakukan pengujian hipotesis. Uji normalitas data menggunakan uji Kolmogorov-Smirnov kemudian dilanjutkan dengan uji homogenitas menggunakan Levene's test yang terdapat pada software SPSS 17. Pengujian hipotesis untuk melihat perbedaan hasil belajar menggunakan uji $t$ dan pengaruh pengunaan metode drill menggunakan analisis regresi.

\section{HASIL DAN PEMBAHASAN}

Kemampuan awal kelas kontrol dan kelas eksperimen ditunjukkan oleh nilai pretest. Hal ini dilakukan dengan tujuan untuk mengungkap kemampuan awal siswa setara atau berbeda saat sebelum diberi perlakuan. Berdasarkan data analisis penelitian ternyata kemampuan awal siswa dari kelas eksperimen dan kelas kontrol berada pada tingkat yang setara.

Rata-rata skor pretest kelas eksperimen didapatkan 38,76 dan rata-rata pretest kelas kontrol adalah 38,05. Maka dapat diketahui bahwa kedua kelas sampel mempunyai rata-rata skor pretest yang relatif sama sebelum diberi treatment. Hal ini juga didukung melalui hasil uji hipotesis terhadap rata-rata skor pretest kelas kontrol dan kelas eksperimen dengan menggunakan uji $\mathrm{t}$ dua pihak, menghasilkan nilai signifikansi lebih rendah dari 0,05 yaitu 0,041, sehingga $\mathrm{H}_{\mathrm{a}}$ ditolak yang artinya rata-rata skor pretest kelas eskperimen sama dengan rata-rata skor pretest kelas kontrol.

Setelah diberikan perlakuan yang berbeda antara kedua kelompok tersebut, dilakukan tes kemampuan akhir siswa yang ditunjukkan oleh nilai posttest. Kemudian dicari dari selisih antara nilai pretest dan posttest. Nilai tersebut sebagai skor gain.

Data hasil belajar berupa skor gain diuji prasyarat yaitu uji normalitas dan uji 
homogenitas. Uji prasyarat ini digunakan sebagai dasar untuk uji selanjutnya akan menggunakan uji parametrik atau non parametrik.

Tabel 2. Data uji normalitas

\begin{tabular}{lll}
\hline Skor & $\begin{array}{l}\text { Asym. Sig. } \\
(2 \text {-tailed })\end{array}$ & Keterangan \\
\hline Kelas eksperimen & 0.389 & Normal \\
Kelas kontrol & 0.078 & Normal \\
\hline
\end{tabular}

Berdasarkan tabel 2, didapatkan nilai signifikansi lebih besar dari nilai $\alpha$ yang digunakan adalah 0,05. Hal ini menunjukan bahwa data hasil belajar siswa dari kedua kelas tersebut berdistribusi normal. Data hasil belajar itu lalu diuji homogenitas. Hasil uji homogenitas disajikan pada tabel 3.

Tabel 3. Data hasil uji homogenitas

\begin{tabular}{lll}
\hline $\mathrm{F}$ & Sig. & Keterangan \\
\hline 0024 & .878 & Homogen \\
\hline
\end{tabular}

Berdasarkan tabel 3, didapatkan nilai signifikansi sebesar 0,878 lebih besar dari $\alpha$ yaitu 0,05 . Hal ini artinya menunjukkan data penilaian memiliki variansi yang homogen.

Hasil uji asumsi klasik yang meliputi uji normalitas, uji kelayakan model regresi dan uji kelayakan regresi setiap data menunjukkan data tersebar berada pada garis lurus, tidak membentuk pola tertentu dan tersebar diantara nilai nol serta sebaran data berada mulai dari kiri lurus keatas. Jadi dapat disimpulkan model regresi memenuhi syarat dari uji asumsi klasik.

Analisis data dilanjutkan dengan uji hipotesis dengan regresi. Hasil uji regresi disajikan pada tabel 4.

Tabel 4. Data hasil regresi

\begin{tabular}{lcc}
\hline \multicolumn{1}{c}{ Model } & \multicolumn{2}{c}{$\begin{array}{c}\text { Unstandardized } \\
\text { Coefficients }\end{array}$} \\
\cline { 2 - 3 } & $\mathrm{B}$ & Std. Error \\
\hline (Constant) & 1,632 & 24,576 \\
\hline Metode drill & 0,758 & .351 \\
\hline
\end{tabular}

Berdasarkan analisis menggunakan uji regresi, menghasilkan nilai koefisien regresi positif sebesar 0,758 yang artinya terdapat pengaruh yang positif antara hasil belajar siswa dengan penggunaan metode drill di kelas.

Selain data diatas juga dicari hubungan dari penggunaan metode drill dalam pembelajaran terhadap hasil belajar dari siswa yang disajikan tabel 5 .

Tabel 5. Hubungan metode drill dan hasil belajar

\begin{tabular}{lll}
\hline Model & $\mathrm{R}$ & R Square \\
\hline 1 & .358 & .729 \\
\hline
\end{tabular}

Berdasarkan tabel 5, didapatkan koefisien determinasi sebasar 0,729. Hal ini menunjukkan bahwa prestasi belajar siswa kelas eksperiemen yang ditunjukkan dengan hasil akhir belajarnya $72,9 \%$ ditentukan oleh penggunaan metode drill dalam penyampaian materi kalor. Sisanya sebesar $27,1 \%$ ditentukan faktor-faktor yang tidak diketahui.

Hasil analisis data di atas menggambarkan bahwa proses belajar siswa dengan metode drill mampu memberikan pengaruh yang baik terhadap hasil akhir dari belajar fisika siswa di MAN 1 Bandar Lampung. Hasil penelitian ini sejalan dengan penelitian M. Wahyudin (2014), bahwa aktivitas pengulangan materi yang dilakukan lebih dari dua kali dengan disertai latihan soal berulang-ulang mampu membuat siswa faham sehingga prestasi belajar meningkat. Bahkan Furlong \& Sharma (2012) menyebutkan bahwa pembelajaran yang memfokuskan pada siswa untuk selalu berlatih dan mempelajari permasalahan akan memupuk kemampuan berpikir dan analisis siswa.

Hasil yang positif itu dikarenakan metode drill sesuai dengan karakter pelajaran fisika yang memerlukan latihan yang bersifat berulang-ulang untuk sampai pada tahap analisis memahami setiap materi. Penguasaan materi dimulai 
dari keterampilan mengerjakan soal tidak berhenti pada satu kali tahap melainkan sampai tahap lanjut. Hal itu dimaksudkan untuk menggali ketangkasan yang lebih dalam dari materi fisika. Aspek ini sangat bagi seluruh siswa karena menjadi syarat dalam mempelajari fisika secara menyeluruh.

Oleh karena itu, metode penyampaian materi yang baik dalam membentuk karakter peserta didik saat metode tersebut memberikan porsi yang lebih besar pada kegiatan siswa. Hal itu sesuai dengan pendapat Harjanto (2006) yang menjelaskan bahwa peningkatan kemampuan siswa dalam memahami materi ditentukan juga oleh metode yang digunakan saat proses pembelajaran.

Menurut Hamalik (2008) kegiatan latihan berulang memiliki manfaat yang sangat besar terutama menyangkut esensi dari fisika sendiri sebagai mata pelajaran sains dengan objek alam yang membutuhkan analisis setiap menyelesaikan suatu masalah. Pendapat tersebut sejalan dengan pernyataan Suyanto (2013) bahwa tugas paling penting dari seorang guru bukan memindahkan materi dari buku ke otak siswa tetapi membuat jalan saja, dengan membearkan siswa mengambil materi dari buku tersebut. Jalan tersebut dibentuk dengan cara memberikan latihan secara terus menerus dengan berbagai konsep untuk memupuk keterampilan pada diri siswa. Proses belajar seperti ini terbukti dapat memberikan pengetahuan baru melalu pengalaman-pengalaman yang tidak diperoleh siswa apabila ia hanya mendengarkan materi dari guru saja.

Kegiatan pemecahan masalah dalam memperoleh hasil akhir bisa dilakukan sendiri tetapi lebih baik secara berkelompok untuk memunculkan sisi sosial siswa yang dapat bermanfaat ketika dia keluar dari sekolah dan hidup di lingkungan masyarakat dengan karekter dan sikap yang berbeda-beda.
Penggunaan metode drill tersebut akhirnya dapat mempengaruhi hasil akhir dari proses belajar siswa. Penelitian ini membahas hasil belajar dari ranah kognitif. Ranah kognitif yang mencakup kegiatan mental. Nilai kognitif siswa merupakan nilai dari aktivitas belajar kemudian dilanjutkan melalui pengerjaan soal pretest dan posttest. Soal berupa soal uraian berjumlah lima soal yang diberikan pada akhir pertemuan. Berdasarkan analisis yang dilakukan pada uji $t$ menghasilkan nilai sig lebih kecil dari 0,05 yaitu 0,033 . Hasil ini menunjukkan bahwa Ho ditolak, yang berarti kedua sampel memiliki variansi yang berbeda. Dengan demikian terdapat perbedaan hasil belajar fisika khususnya pada materi kalor antara siswa dalam pemmbelajaran menggunakan metode drill dan siswa dengan metode ceramah.

Peningkatan hasil belajar saat kegiatan belajar melalui metode drill menunjukan bahwa siswa lebih termotivasi saat mereka terlibat secara langsung dalam kegiatan belajar-mengajar. Metode drill menekankan peran siswa untuk terlibat secara langsung dalam membangun suasana yang tepat dalam proses pembelajaran agar muncul suatu kondisi dimana setiap siswa memiliki pengetahuan dan kecakapan yang mumpuni. Hal ini diperkuat dengan pendapat Djamarah (2008) yang menjelaskan bahwa belajar materi termasuk didalamnya terdapat latihan. Latihan merupakan bagian penting dalam penguatan konsep materi sehingga semakin banyak latihan yang dilakukan siswa maka kesan terhadap materi tersebut semakin sulit dilupakan. Juga penelitian dari Meta Aditya Handayani (2014) yang menunjukkan metode drill efektif digunakan dalam pembelajaran, hal itu dibuktikan dengan meningkatnya nilai akhir siswa pada kelas eksperimen.

Hasil di atas ternyata sama dengan penelitian Aryantini (2011) bahwa adanya perbedaan yang signifikan hasil belajar 
fisika dikarenakan penggunaan metode drill mampu merubah persepsi siswa tentang fisika dibandingkan metode ceramah. Hasil belajar kemampuan yang diperoleh siswa setelah melalui kegiatan pembelajaran, nilai rata-rata tes akhir kelas eksperimen lebih besar yaitu 75.56 dibandingkan dengan kelas kontrol yaitu 68,13 . begitu juga dengan rata-rata nilai gain pada kelas eksperimen lebih besar yaitu 39,21 dibandingkan dengan kelas kontrol yaitu 16.,7. Perbedaan dan variasi hasil belajar para siswa disebabkan oleh fakor-faktor kematangan, latar belakang pribadi, sikap dan bakat terhadap pelajaran, dan jenis mata pelajaran yang diberikan.

\section{SIMPULAN}

Berdasarkan hasil penelitian dan pembahasan disimpulkan bahwa :

1. Terdapat perbedaan hasil belajar fisika antara siswa yang diajar menggunakan metode drill dengan siswa menggunakan metode ceramah yang ditunjukkan oleh nilai signifikansi pada uji $t$ sebesar 0,033 lebih kecil dari 0,05 .

2. Terdapat pengaruh penggunaan metode drill terhadap hasil belajar kognitif siswa kelas $\mathrm{X}$ MAN 1 Bandar Lampung yang ditunjukkan oleh nilai koefisien regresi positif sebesar 0,758 .

\section{SARAN}

Bagi guru fisika khususnya peneliti kelas X di MAN 1 Bandar Lampung agar dapat menjadikan metode drill sebagai salah satu alternatif solusi untuk meningkatkan nilai akhir siswa sebagai cerminan prestasi belajarnya. Penulis mengharapkan adanya penelitian lanjutan tentang metode drill yang membahas materi fisika pada bab lain tidak terbatas pada kalor juga variabel yang diteliti tidak terbatas pada hasil belajar melainkan juga pada aspek lainnya. Siswa yang masih belum fokus dan selalu membuat gaduh seperti melakukan kegiatan yang tidak berhubungan dengan materi perlu diberikan perhatian dan penanganan secara khusus agar tidak mengganggu siswa yang lain.

\section{DAFTAR PUSTAKA}

Arikunto, S. (2010). Dasar-Dasar Evaluasi Pendidikan. Jakarta: Bumi Aksara.

Aryantini. 2011. Pengaruh Penggunaan Metode Drill Terhadap Hasil Belajar Fisika Siswa MAN 1 Bandar Lampung Tahun Ajaran 2010/2011 (Unpublsished Skripsi). Universitas Lampung, Bandar Lampung.

Bruce, J \& Marshal, W. (2000). Models of Teaching $6^{\text {th }}$ Edition. New Jersey: Prentice-Hall.

Dahar, R. W. (1989). Teori-Teori Belajar. Jakarta: Erlangga.

Djamarah, S. B. (2008). Psikologi Pendidikan. Jakarta: Rineka Cipta.

Furlong, K. P. \& Sharma, P. (2012). Effects of Active Learning on Enhancing Student Critical Thinking in an Undergraduate General Science Course. Innovation High Education, 223235.

Hamalik, O. (2008). Kurikulum dan Pembelajaran. Jakarta: Bumi Aksara.

Handayani, M. A. (2014). Efektivitas Metode Drill Berbantuan Modul Pembelajaran Dalam Upaya Meningkatkan Hasil Belajar Siswa SMA Negeri 10 Semarang Tahun Ajaran 2013/2014. Economic Education Analysis Journal, 2 (3) 68-74.

Harjanto. (2006). Perencanaan Pembelajaran. Jakarta: Rineka Cipta.

Purwati, P. (2010). Pengaruh Penerapan Metode Drill/Latihan terhadap Minat Belajar Siswa. Jurnal 
Pendidikan Universitas Garut, 4 (1) 48-53.

Roestiyah. (2008). Strategi Belajar Mengajar. Jakarta: Rineka Cipta.

Sanjaya, W. (2008). Strategi Pembelajaran Berorientasi Standar Proses Pendidikan. Jakarta: Kencana.

Sriyono. (1992). Teknik Belajar Mengajar dalam CBSA. Jakarta: Rineka Cipta.

Sukmadinata, N. S. (2011). Metode Penelitian Pendidikan. Bandung: Rosdakarya.

Susilowati, E. (2013). Penggunaan Metode Pembelajaran Drill sebagai Upaya Meningkatkan Prestasi Belajar Siswa. Jurnal Pendidikan Ekonomi FKIP UNS, 1 (3) 242-250.

Suyanto \& Jihad, A., (2013). Menjadi Guru Profesional: Strategi Meningkatkan Kualifikasi dan Kualitas di Era Globalisasi. Jakarta: Esensi, Erlangga Group.

Wahyudin, M. (2014). Pengaruh Penggunaan Metode Drill terhadap Hasil Belajar IPS Siswa (Unpublished Skripsi). UIN Syarif Hidayatullah, Jakarta.

Wilson, L. O. (2013). New blooms in established fields: four domains of learning and doing. Retrieved from

http://goliath.ecnext.com/coms2/gi _0199-5400788/New-blooms-inestablished-fields.html

Winkel, W. S. (2009). Psikologi Pengajaran. Yogyakarta: Media Abadi.

Zamroni. (2000). Paradigma Pendidikan Masa Depan. Yogyakarta: Biagraf Publishing. 